\title{
Michał Kmieć
}

Cardinal Stefan Wyszyński University in Warsaw, Poland

\section{Paradoksy współczesnych Europejczyków Recenzja książki Chantal Delsol \\ pt. Kamienie wegielne. Na czym nam zależy?, tł. M. Kowalska, Znak, Kraków 2018, ss. 352.}

Chantal Delsol jest francuską filozofką, dobrze znaną polskiemu czytelnikowi, identyfikowaną jako osoba, która reprezentuje poglądy na Zachodzie, oględnie mówiąc, niepopularne. Wydana przez Wydawnictwo Znak książka Kamienie wegielne. Na czym nam zależy to kolejny głośny apel tej wybitnej intelektualistki do Europejczyków, w tym także i do Polaków, obok którego nie sposób przejść obojętnie ze względu na treść i język, który porusza struny duszy i zmusza do refleksji.

Książka w swoim zamyśle charakteryzuje „kamienie węgielne” europejskiej kultury, a właściwie cywilizacji. Są to kolejno: osoba ludzka, radość, nadzieja, prawda i transcendencja. Kamienie te stanowią odpowiedź na tytułowe pytanie: na czym nam (Europejczykom) zależy w życiu najbardziej. Delsol przekonuje nas, że właśnie te pojęcia głęboko tkwią w naszym życiu społecznym, to na nich ono się opiera a próba pozbycia się ich doprowadzi wprost do katastrofy ludzkości. W tym kontekście należy zauważyć pierwszą oznakę postnowoczesności myślenia Delsol. Nie pyta ona o to, co jest dobre i prawdziwe, lecz bada nasze pragnienia i potrzeby. Można odnieść wrażenie, że książka posiada wymiar nie tyle pragmatyczny, co wręcz utylitarny.

Europejski fundament został wybudowany na gruncie judeochrześcijaństwa. Pozbycie się religii z życia sprawiło, że Europa wraca do idei, które religię Chrystusową poprzedzały, bądź też przyjmuje idee, które do tej pory istniały obok chrześcijaństwa. Interesujące w tym kontekście wydają się być rozważania na temat eugeniki. Europa, odrzuciwszy chrześcijaństwo, wraca do myśli Platona i Arystotelesa, które ta religia oczyściła i odrzuciła. Nie może jednak przyjąć dziedzictwa greckich filozofów, które chrześcijaństwo przyjęło jako swoje, bowiem utożsamiane jest ono już tylko z nim. 
W postnowoczesnej Europie tkwi głęboki paradoks. Kultura europejska charakteryzuje się głęboką niespójnością. Chantal Delsol pokazuje, że nieustannie odrzucamy kamienie wegielne, na których, w gruncie rzeczy, nam najbardziej zależy, które w sposób nieświadomy są czymś jak najbardziej pożądanym. Jednakże myśl Delsol również charakteryzuje się niespójnością. Z jednej strony zauważa, że usunięcie źródła sprawiło, że takie pojęcia jak wolność czy godność stały się puste. $Z$ drugiej zaś Delsol przyjmuje postnowoczesność jako swoją. Adaptuje pewien postmodernistyczny sposób myślenia i mówienia o rzeczywistości, i nie tylko po to, by porozumieć się ze współczesnym czytelnikiem. Ciekawym faktem jest również to, że wspomina często o innych niż europejska kulturach, które wcale „nie mają się gorzej”, jakby chciała przekreślić wszelkie „tradycyjne przywiązanie”, wręcz zabobonne, do tego co własne, do tego co jej, co byłoby swoistym paradoksem. Książka przecież została napisana z miłości.

Rozdział pierwszy poświęcony jest omówieniu koncepcji osoby ludzkiej i jej godności. To najważniejsza część tej książki i chyba najbardziej niespójna w swych niejednoznacznych konkluzjach. Współczesny świat w rozwoju nauk biologicznych postrzega człowieka jako zwierzę całkowite zniewolone swą naturą. Jednak w obliczu katastrofy drugiej wojny światowej człowiek staje się najwyższą wartością. Ten paradoks rodzi przeróżne problemy. Wspomniany rozdział stawia pytanie: czy my, ludzie, chcemy po prostu być? Nie otrzymujemy wyczerpującej odpowiedzi. Przez słowa autorki przebija się niejasna idea bycia dla samego bycia. Choć Delsol wyraża smutek z powodu wymycia chrześcijańskiego znaczenia owych kamieni wegielnych, ostatecznie przyjmuje to za fakt i uznaje, że odwoływanie się do tych znaczeń byłoby niezrozumiałe dla jej czytelników (s. 29). Wiara zmienia się w tradycje społeczne, będące jedynie preferencją, której nie można dowieść. Godności osoby ludzkiej, twierdzi, trzeba bronić, ale nie tak jak wcześniej (znaczy bez odwołania do chrześcijaństwa). Problem polega na tym, że odarcie z racjonalizmu chrześcijańskiego kamieni węgielnych zmienia sposób ujęcia relacji społecznych. Zamiast etyki personalistycznej pojawia się logika pragmatyzmu czy nawet utylitaryzmu społecznego. Godność ludzka staje się u Delsol pojęciem technicznym. Celem obrony kamieni węgielnych jest ochrona ludzkości jako takiej. Skoro godność, prawda czy nadzieja nie są warte ochrony ze względu na to, ze są czymś dobrym, prawdziwym, to stają się jedynie narzędziami ocalenia ludzi dla samego bycia. Jedynym celem staje się przetrwanie człowieka. Autorka przyznaje jednak, że bez duchowości, bez religii koncepcja godności upadnie. Jeśli bowiem Panem życia nie jest już Bóg, to jest nim społeczeństwo, które decyduje o tym, kto powinien żyć (s. 64). Czy zatem można twierdzić, że 
nieistotny jest fakt, iż godność wywodząca się z koncepcji Boga została utracona na rzecz konstruktu tradycji społecznej czy mitu? Czy rzeczywiście istotne jest tylko to, że musimy tę koncepcję obronić? Tym bardziej, że bronimy tego z powodu doświadczenia zła (Holokaustu). Czy faktycznie zło może nas skłonić do zachowania godności ludzkiej?

I tu pojawiają się kolejne ciekawe rozważania. Delsol z optymizmem podchodzi do myśli ekologicznej, która ma naprawić wiele błędów postnowoczesności. Ekologia uczy bowiem o obiektywnej rzeczywistości, o prawie danym ludziom, a nie przez nich stworzonym. Ten optymizm jest zaskakujący - stronnictwa ekologiczne są dzisiaj kojarzone jawnie ze światem antychrześcijańskim. Delsol przyznaje, że człowiek bez Boga przyznaje sobie status Absolutu w sposób naturalny. Jednak nie staje w pełni po stronie obiektywnej prawdy. Jej celem jest zwalczanie zła.

Kolejny rozdział rozprawia się z koncepcją szczęścia na rzecz radości. Ten rozdział z kolei wydaje się najbardziej spójny. Szczęście to koncepcja, która usypia Europejczyków. Uznano, że najlepszy dla ludzkości będzie brak myślenia, zadawania sobie najtrudniejszych pytań, by osiągnąć błogi spokój. Ludzkość zajmuje się jedynie złem, w którego cieniu tkwi. Jedyne, co jesteśmy w stanie zrobić, to ustawić kilka „znaków” w miejscach, gdzie naprawdę możemy się skrzywdzić. To nam wystarcza.

Rozdział trzeci ukazuje Delsol jako człowieka nadziei. Nie wszystko jest stracone. Pisze, bo ma nadzieję. Człowiek, przypomina, nie jest samowystarczalny. Przeciwnie, potrzebuje do życia innych, a także nadziei na osiągnięcie dobra, do którego dąży. Dzięki nadziei jesteśmy strażnikami tego, czego sami nie tworzymy. Została ona wyrugowana z życia publicznego, ponieważ nakłada obowiązek czekania na cud. Nowoczesny racjonalista odrzuca wszelką obietnicę i wszelką tajemnicę. Obietnica zbawienia jest kluczowa dla postępu. Postęp dany jest tylko w momencie, kiedy widzimy coś poza rzeczywistością. Możliwy jest, tylko gdy przyjmujemy dziedzictwo historii. Delsol, pisząc o postępie, rozważa go przez pryzmat pojęcia emancypacji społeczeństwa, ukazując, moim zdaniem, niesłusznie, zacofanie katolicyzmu na tym polu (wytyka choćby poparcie dla niewolnictwa, pomimo wielu dokumentów Magisterium świadczących o czymś zupełnie przeciwnym). Miejscami można odnieść wrażenie, że Delsol uprawia na swój sposób „nową teologię polityczną”, zainicjowaną przez J.B. Metza. Kamienie węgielne służyć mają ludzkości do emancypacji od różnych form zła. W książce przeczytać nawet możemy, że Chrystus, którego Europa odrzuciła, pozostawił 
po sobie koncepcję wyzwolenia od zła doczesnego (s. 196). A te wszystkie rozważania wieńczy stwierdzeniem, że nadzieja jak i postęp bez koncepcji zbawienia upadną. Utrata nadziei rodzi nihilizm. Nadzieja jest cnotą boską. Czy bez Boga jesteśmy w stanie ocalić nadzieję? Na to pytanie Delsol nie odpowiada w sposób jednoznaczny.

Rozdział czwarty poświęcony jest prawdzie jako gwarancji wolności. To bardzo mocne nawiązanie do Ewangelii. Prawda wyzwala człowieka. To niezwykle trudne słowa w świecie, który prawdę utożsamia z fanatyzmem. Rozdział ten zawiera w sobie jeszcze więcej paradoksów. Raz Delsol wspomina o tym, że prawda sama się narzuca, że przychodzi z zewnątrz (s. 236). Kiedy indziej powie: „Prawda nie jest więc dana z góry i nie narzuca swej uniwersalności, lecz wyłania się z konkretnego powszechnika. Obdarza nas racjonalnością bardziej poetycką niż naukową" (s. 272). Kiedy indziej powie, że Prawdy nie można posiadać, lecz można jej tylko szukać. Czy zatem prawda sama w sobie, aby nie przeobraziła się w fanatyzm musi być niepewna? Jak to pogodzić z Chrystusem, który mówi o sobie, że jest Prawdą? To nie prawda stanowi problem, lecz jej oderwanie od miłości.

Ostatni rozdział, choć powinien być poświęcony koncepcji Boga, nie jest jednak prostą obroną religii i wiary. Delsol nie ukazuje dobra, które niesie ze sobą wiara. Walczy z ateizmem jako czymś szkodliwym dla wspólnoty politycznej. Zaskakujące uwagi czyni na temat naturalności politeizmu, co w świetle współczesnych badań wydaje się być co najmniej problematyczne. Ateizm jest walką z chrześcijaństwem, które stanowi o istocie kamieni węgielnych. Delsol zdaje sobie sprawę, że nie można zbudować jedności wspólnoty politycznej bez stanowiska, które należałoby określić jako agnostycyzm $\dot{z} y c z l i w y$. Jest to postawa jawnie odmawiająca wsparcia Boga jako rzeczywistości, lecz sceptycznie podchodząca do całkowitego odrzucenia Jego istnienia. Odrzucenie Boga, powie Delsol, sprawiło, że ludzie przestali zadawać pytania egzystencjalne. A jest to niezbędne dla normalnego funkcjonowania człowieka w tym świecie. Każdy, kto wychyla się w tę stronę, uznawany jest za osobę chorą psychicznie, i to właśnie stanowi postnowoczesny totalitaryzm.

Ostatecznie Delsol jasno przyznaje, że opisane przez nią kamienie węgielne nie powstały ot tak, lecz są dziedzictwem kultury judeochrześcijańskiej. Co więcej, zdecydowanie stwierdza, że współczesny schyłek chrześcijaństwa nie jest jego końcem. Jest ono wieczne, nie da się go zniszczyć. Można zatem uznać, że dopiero w końcowych konkluzjach Delsol staje w obronie wiary w Ewangelię. 
Chantal Delsol ofiaruje nam niezwykle ciekawą książkę, będącą opisem upadku Zachodu i obroną wartości, na których nam najbardziej zależy. Myślę, że trafnie zdiagnozowała te wartości. Delsol jednak porusza się nieustannie w cieniu zła (a konkretnie w obliczu historii Holokaustu). Broni wartości, chcąc uchronić Europę od ponownego doświadczenia cierpienia. W rzeczywistości opłakuje śmierć Boga. Adam i Ewa znając dobro, przez grzech poznali także zło. Delsol prowadzi dialog ze światem, który utracił znajomość dobra jako takiego. Współcześni ludzie znają tylko zło. Można by odnieść wrażenie, że dialog z nimi można prowadzić tylko poprzez negację zła. Jak zauważa tłumaczka książki na język polski „nie jest to solidny fundament, ale nic lepszego chyba mieć nie będziemy" (s. 347). Byłaby to smutna konstatacja. Chrześcijanin jednak żyje w pełnym świetle dobra i prawdy. Metoda Delsol na pierwszy rzut oka wydaje się piękna, ale - jak się wydaje - nie dotyka istoty problemu. 